\title{
EAl Endorsed Transactions

\section{A Proposal on Techno-Financial Design aspects of Photovoltaic System for the Twin Districts of Rajouri and Poonch (Jammu \& Kashmir)}

\author{
Shafqat Nabi Mughal ${ }^{1, *}$, Yog Raj Sood ${ }^{2}$ and R.K. Jarial ${ }^{3}$ \\ ${ }^{1}$ Assistant Professor, Department of Electrical Engineering, Baba Ghulam Shah Badshah University, Rajouri (J\&K) India. \\ ${ }^{2}$ Professor, Department of Electrical Engineering, National Institute of Technology, Hamirpur (H.P) India. \\ ${ }^{3}$ Associate Professor, Department of Electrical Engineering, National Institute of Technology, Hamirpur (H.P) India.
}

\section{Abstract}

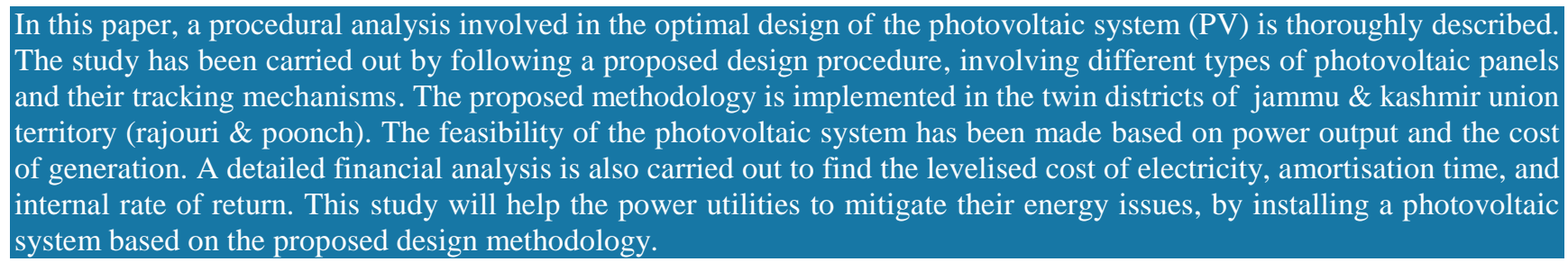

Keywords: cost estimation, design, photovoltaics, renewable energy, solar power

Received on 02 May 2020, accepted on 12 July 2020, published on 17 July 2020

\begin{abstract}
Copyright (C) 2020 Shafqat Nabi Mughal et al., licensed to EAI. This is an open access article distributed under the terms of the Creative Commons Attribution licence (http://creativecommons.org/licenses/by/3.0/), which permits unlimited use, distribution and reproduction in any medium so long as the original work is properly cited.
\end{abstract}

doi: 10.4108/eai.13-7-2018.165521

\section{Introduction}

The global energy demand has tremendously spiked in the past, due to the increase in the human population and industrial development. This has created a large pressure on the generation entities, to increase their generation. To overcome this energy deficit, Renewable energy systems are a good option, due to the stable improvement in renewable energy technologies and green nature. There are different types of renewable energy sources (like solar, wind, etc.) which could be used as an alternative to conventional energy sytems[1-3].Some innovative sources of alternative energy generations were also found in the literature,For example in [4] a technical solution for converting the kinetic energy of press into electric power and accumulating it for further use, is proposed.In [5] a research is conducted based on the selection of the engine and windings to convert the kinetic and mechanical energy of rotation in the electric one.Also in [6] the use of microalgae to produce bio enegy is given.
Microalgae are believed having high rate of photosynthetic activities producing good amount of power.Mass cultivation of microalgae can reduce the carbon dioxide emission to atmosphere and thus,reducing the impact of global warming.

Among these vatious alternative energy sources, Solar energy is the most widely used, due to its abundant availability and green nature. The use of Solar energy is advancing very rapidly throughout the whole world. During the last decade there is an abrupt increase in the use of solar energy seen. A large number of photovoltaic (PV) systems have been installed globally and the annual growth rate between 2010 and 2017 was as high as 24\%[7].According to Bloomberg, the global benchmark levelized cost of electricity(LCOE) for onshore utility-scale PV systems has fallen $4 \%$ since the second half of 2019 to $\$ 50 / \mathrm{MWh}[8]$.

India, too, has realized its solar potential and various developments could be seen, to expand the dependence on this form of energy. The estimated solar energy incidence in the Indian mainland is approximately 5000 trillion kilowatthours $(\mathrm{kWh})$ per year [9-10] which is higher than the possible

*Corresponding Author. Email:snmughal@bgsbu.ac.in 
energy output through all fossil reserves. The total installed capacity of solar power has reached 34 Gigawatts $(\mathrm{GW})$ by Feb-2020 in India [11]. The major portion of the installed capacity is ground-mounted, comprising of mega solar power projects, which are producing power centrally and feeding to the grid. The remaining is rooftop solar, which includes residential, industrial, and commercial deployments. By July2019 , the ground-mounted and rooftop capacity has reached 27,930 Megawatts (MW) and 2,141 Megawatts (MW) respectively. India has intended a commitment, to achieve $40 \%$ of its total electricity generation,from renewable energy sources by 2030 in the Paris agreement.

In supplement to the grid-connected solar power initiatives, India is also developing off-grid solar power,through local producers [12]. Many solar products,such as solar lanterns, solar inverters, solar geysers, etc had been distributed by the government,either free or on subsidized rates to meet rural needs [13]. This is an outcome of continuous improvements in solar industries. However, despite these developments in the solar industry, there are several areas of Jammu \& Kashmir Union territory(J \& K UT), which are still power deficient, due to poor transmission and distribution infrastructure. These areas are also hesitant to use solar power, due to the lack of technological understanding. The capacity additions in solar power, which were made, were either of too low capacity or underutilized, resulting in too low voltages in some areas, especially in the Rajouri \& Poonch district of J \& K UT [14].

\section{Problem Formulation}

The J \& K UT is most probably the only piece of land on the world map, that despite being profusely rich in many resources of self-reliance $\&$ self-satisfaction has not reaped their benefit to its full advantage. Till date, people of J \& K UT, especially, twin border districts of Pir Panjal range (Rajouri \& Pooch), have to face power cuts of several hours, more during the cold weathers of winter, with erratic \& intermittent power supply.

It despite having a generation capacity of 20,000 Megawatts (MW), is often considered as the energy-starved regions within India [15].The main reason of this energy starvation is due to its dependence, on the hydro energy sources, which in winters fail to supply, due to the reduction in the water level in the rivers.Also an increase in energy demand is seen during winters, due to the increase in the use of heating appliances etc. Under these situations, they are meeting their energy demands throught the use of thermal generating plants, diesel generators, etc.

In addition, there are heavy transmission and distribution losses in J \& K UT, due to its poor infrastructure. Due to these contions, this region has seen, power cuts of several hours and an increase in the finances. There are several areas such as (Rajouri and Poonch) which remain without power for several days and weeks. The rising energy demands in J \& K UT, are creating a shortfall of more than $400 \mathrm{MW}$ during winters [16].This shortfall is expected to increase, in the future, if concrete measures were not taken.

The J \& K UT, however has a huge potential of renewable energy sources, especially Photovoltaics (PV). But, due to the technological \& political backdrop, it has not been harnessed well and efficiently so far. To cope up with this energy starvation, there is an urgency to shift the focus, towards solar energy, as this region is quite rich in receiving good amount of solar radiations.Also, solar energy technology is currently experiencing a boost due to technological improvements and the cost of electricity generated through solar has crossed grid parity [17]. Moreover governments, are offering various incentive schemes, to achieve their renewable energy targets. Some of these are as follows:

\section{(i) Accelerated Depreciation}

By Accelerated depreciation, utilities can claim depreciation in the Ist year, by installing Photovoltaic (PV) systems. This will benefit them in tax saving, to gain some profit.

\section{(ii) Capital Subsidies}

The central government as per Ministry of New \& Renewable Energy (MNRE) is offering capital subsidies of $30 \%$ on the benchmark cost for PV systems (Rooftop) in the general category states. However in certain special states like Himachal Pradesh, Sikkim, Uttarakhand, the offered subsidy is $70 \%$ on the benchmark cost [18].

\section{(iii) Renewable Energy Certificates}

These are special certificates that can be traded for the generation of electricity from renewable energy sources. This will help the states to achieve renewable power obligations (RPO) set up by the central government.

\section{(iv) Net Metering Incentives}

By Net metering, a consumer can trade the electricity which he had generated with the local energy distributors. However this is dependent upon the incentive policy mechanism incentives offered by the state.

\section{(v) Assured Power Purchase Agreement (PPA)}

According to this agreement, any power producing or power utilizing company owned by central or state governments are guaranteeing the selling and buying of power for a certain period of contract. As far as distribution generation is concerned commercial PPAs are used by many schools, NGOs, etc. to purchase power other than the utilities. By this mechanism many incentives are offered to set up small distribution setups like Photovoltaics etc.

In this research work, we have given a detailed analysis, regarding the design of Photovoltaic (PV) systems with current technology breakthrough. A thorough investigation has also been carried out, for the twin districts of Rajouri \& Poonch $(\mathrm{J} \& \mathrm{~K})$ indicating a good solar power reserve along with cost analysis. 


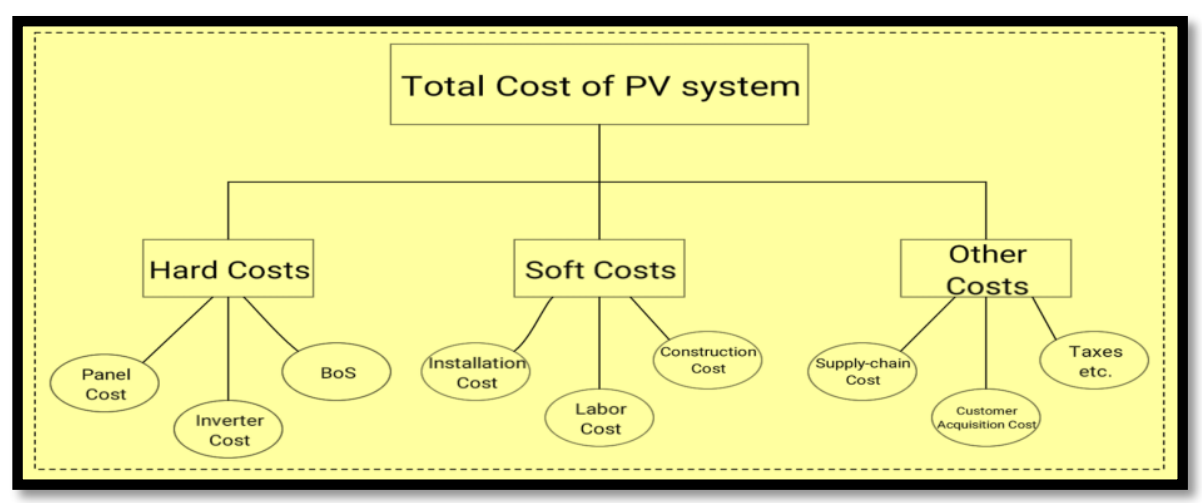

Figure.1 Composition of total cost of PV system

\section{Design Method to Harness Photovoltaic Power}

To set up a PV systemt, in order to harness solar energy, there are various steps involved, in the selection, design, determining specifications, etc.These steps vary, depending upon various attributes such as geographical location, solar irradiation levels, and local weather condition, etc. of the site[19]. The power output of the PV system is directly related to these attributes. Moreover this power output also depends on the type of solar module used, different types of solar radiation tracking mechanisms adopted, tilt angle of solar panels etc.

The expenditure on the installation of PV system has declined, owing to the reduction in the pricing of the various equipements involved in PV system. The reduction is by over $70 \%$,during the last few years. This decrease, is a result of the technological breakthrough and rising energy demand of the utilities. The overall cost of the PV system is broadly divided into hardware costs, soft costs, and other costs.Figure.1 shows the various PV cost compositions. Hardware costs comprise the costs associated with solar Modules, Inverters, charge controllers, batteries, etc. Soft costs are the costs associated with financing for installation, labour, etc. Also the other costs involve money spent on customers and taxes to be paid.
This research work aims to harness the maximum amount of solar energy in the twin district Rajouri and Poonch of Jammu and Kashmir UT. Both the regions being hilly, are posing challenges to set up new power corridors. Due to this hindrance, a large number of populations suffer from lack of electricity. By designing a PV system, the shortage of electricity will be overcome to a large extent. But to grasp maximum electricity from PV system many design factors need to be investigated for correct sizing.

The important factors which affects solar panel output is as follows:

- $\quad$ Type of Photovoltaic (PV) modules used

- Tilt/ Angle of Inclination

- Array tracking designs

- Systems losses

- Shading

- Temperature

\subsection{Types of PV modules}

Different variety of Photovoltaic (PV) modules are accessible in the market. These are broadly classified into Monocrystalline and Polycrystalline solar panels. Monocrystalline is manufactured from a single crystal and has the highest conversion efficiency of $20 \%$. However Polycrystalline is manufactured from different crystals with a conversion efficiency of $14 \%$. Apart from them, there are

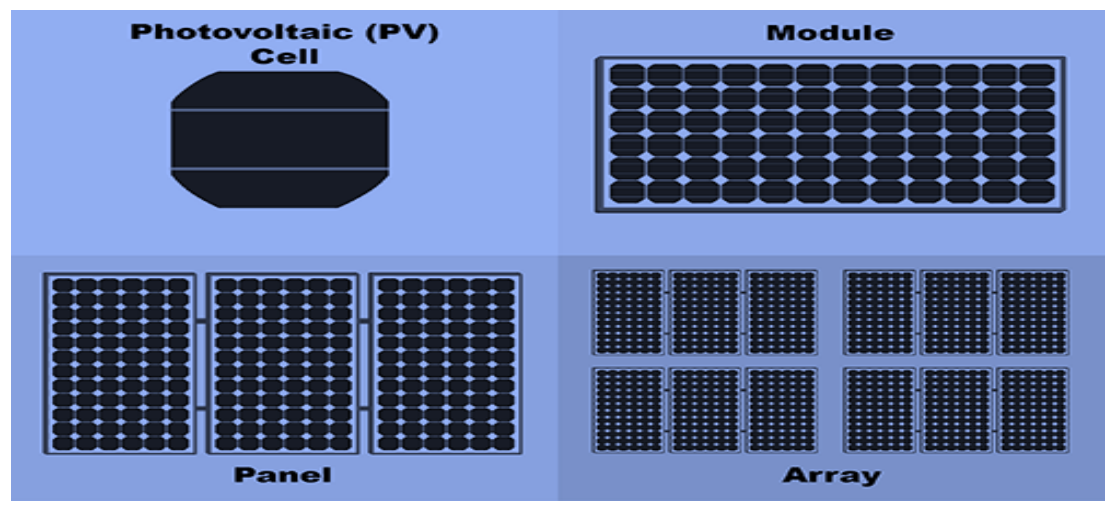

Figure.2 A journey from solar cell to solar array[27] 
also amorphous solar panels available. They are least efficient but highly flexible.

These solar modules can be connected in series and parallel combinations, to get the desired current and voltage ratings as per the requirement of the load and other parameters. Solar modules connected in series result in increase in voltage, while when connected in parallel causes increase in current. These solar panels provide the rated output at standard testing conditions (STC) only.However in varied conditions of weather,there is shift in power output.Also the power output of PV panel depends upon the matrial of the PV panel as well.A research was conducted in [20], whereby the authors discussed and analysed various existing types of silicon PV panels. They illustrated the various load parameter conditions for transmitting maximum power into the load.In [21] a research was carried out to analyse the impact of radiations on the efficiencies of different types of PV Panels. A schematic diagram showing transition from solar cell to solar array is shown in Figure.2.

\subsection{Solar Array Tracking designs}

There are three types of solar array designs: fixed, single-axis tracker, and double-axis tracker. The double-axis tracker is the most efficient one, to tap a large number of solar radiations and eventually increasing the power output followed by single-axis tracking and fixed designs. The choice is dependent upon the end-user, by taking into consideration various factors like weather conditions, the terrain of the site, economy, etc. Figure. 3 shows different types of tracking designs.

Based on various surveys conducted, generally the end-users prefer tracking system design rather than a fixed ground system, as a way to increase their power outputs. Investment in the automatic solar tracking system will yield a definite good return.It can contribute greatly to the welfare of humans, in reducing the greenhouse effect, while achieving continual abundant energy supplies. The yield from the solar panels increases by 30 to $50 \%$ using a tracker instead of fixed solar panels. There is an urgent requirement of the automatic sun following trackers in the future, because of following inefficient methods of tracking given in Table. I

\section{Table. I Comparison of different solar panels}

\begin{tabular}{l|l|l}
\hline S.No & Method & Reasons for inefficiency. \\
\hline 1 & $\begin{array}{l}\text { Fixed angle Solar } \\
\text { Panels }\end{array}$ & $\begin{array}{l}\text { It is least efficient, owing to } \\
\text { the change in position of sun } \\
\text { during different times of the } \\
\text { day. }\end{array}$ \\
\hline 2 & $\begin{array}{l}\text { Manually rotated } \\
\text { Solar Panels }\end{array}$ & $\begin{array}{l}\text { A large amount of } \\
\text { manpower is needed to shift } \\
\text { the tilt angle of the solar } \\
\text { panel, which is not logical. }\end{array}$ \\
\hline 3 & $\begin{array}{l}\text { Predefined rotated } \\
\text { Solar Panels using } \\
\text { programmed } \\
\text { software/timers. }\end{array}$ & $\begin{array}{l}\text { It becomes inefficient when } \\
\text { sun gets blocked by clouds, } \\
\text { while it still changing its } \\
\text { position and wasting power }\end{array}$ \\
\hline
\end{tabular}

\subsection{Tilt Angle and Azimuth}

The tilt angle is the angle which solar panels make with the horizontal surface. In the case of single-axis tracking systems, it's the angle of the tracking axis with the horizontal surface. This is required to get the maximum amount of solar radiations incident on the solar panel. To optimally receive the solar radiations on the surface of the solar panel, the tilt angle is required to be changed based on seasonal variations [22]. However it's better to keep it fixed; equal to the latitude of the given location, instead of changing it every time, involving manual labour. As far as Azimuth is concerned, for south-facing solar panels, it is kept equal to $180^{\circ}$ and for north facing solar panels its kept equal to $0^{0}$.

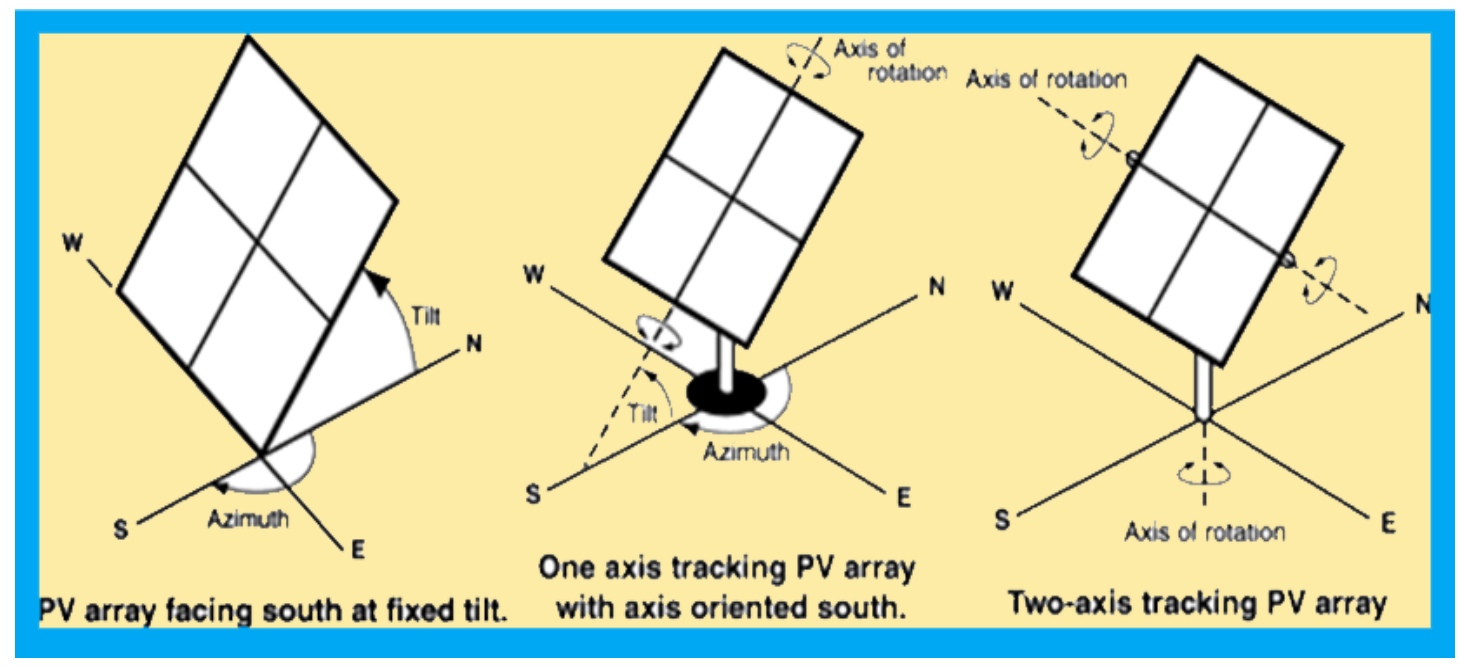

Figure.3 Different types of tracking mechanisms[26] 


\subsection{System Losses}

A Photovoltaic system is often subjected to different types of losses. These losses results in the power supplied through PV panels different, than the power for which it was actually tested at standard testing conditions (STCs).An approximate estimation of these losses, can be very beneficial, while designing the PV setup .Following are the different types of losses which takes place in the PV system.

(i) Losses due to Reflection

The power output of PV system is differnet under outdoor conditions.This is due to the larger incidence angles of the solar radiations, resulting in higher reflection losses than under standard testing conditions.Under STCs, the incident radiations are kept perpendicular.The estimated value of reflection losses for PV panels facing equator with tilt angle equal to the latitude are about $1 \%$ yearly than at STCs.

\section{(ii) Losses due to Soiling}

These losses, are on account of acculmulated dust and foreign particles present on the surface of the PV panels. This causes decrease in the power output of PV panels, because of the decrease in solar radiations penetrating them.The soiling losses depends upon the weather and the location of the site.For example in heavy traffic places,industrial places etc the dust accumulation is very frequent.Also in certain situations like snow, the power output depends on the amount and the time for which it remains on the PV panels.Many organisations like NREL are doing research to model the impact of these losses on the power output.

\section{(iii) Losses due to Module Mismatch}

No two PV modules can be exactly same, resulting in the mismatch losses, when these are connected in series and parallel.This is due to the difference in the manufacturing methods adopted and conditions to which they are subjected. Mismatch losses can be a serious problem, while evaluating the power output of the PV array.For worst case scenario the power output of the PV array is determined by the solar module with the lowest power output. Therefore, it becomes very essential, to select the modules with less mismatch,so that the overall power output doesn't change much.

\section{(iv) Losses due to MPPT}

There exists a single point on the PV curve of the solar module, when the power delivered is maximum.In order to continuously supply the power output at maximum,a Maximum Power Point Tracker (MPPT) is desirable.MPPT is basically a dc to dc converter which transfers the maximum power from the solar panels to the load.There are various types of MPPTs available in the market.The correct selection of these is imperative, to ensure that the power output is always maximum.The wrong rating of the MPPTs could drastically reduce the power output of the PV panels. Hence a great care should be taken while choosing the right MPPT for the PV system.

\section{(v) Losses due to Wiring}

These are Resistive losses due to the use of DC and AC wires, for connecting different PV modules, Inverters and load points.A poor wiring can cause heavy loss in power output of the PV system.

The system losses described above, if not taken into consideration, could result in the poor estimation of the power output of the PV system. This can pose a great threat to the stability electricity grid. Hence a great care has to be taken to correctly estimate them.

\subsection{Shading}

Solar radiations falling on the PV panel gets largely affected due to the shadow caused by big objects such as trees, buildings present aroung the PV arrays.Sometimes even the shadow of one PV array falls on the other PV array resulting in loss of power output.

The power output from the solar panels gets affected to a large extent even if only a part of its gets shaded. Therefore great care has to be taken to ensure no solar panel gets shaded due to other panels shadow etc. This could be done by keeping the proper spacing between the different rows of solar panels. Also, dust, etc. leads to shading, so it needs to be cleaned at regular intervals.

It could had been better to setup PV system, where there is no shade present, to minimise this loss.But this is an ideal condition and not always possible.In practical situations bypass diodes are used to minimise the power loss. These are connected between the cells in the PV module.These provide an alternate path for the currents of unshaded portion thereby restricting their flow into the shaded portion.Although, a small voltage drop occurs, but, still its not much, if no diodes are used.

\subsection{Temperature}

The power output mentioned on the PV panel is at standard testing condition (STCs), under which the temperature is kept around $25^{\circ}$ C.However, the temperature under outdoor conditions is variable, resulting in the variation of power output of the PV panel.Higher temperature, results in the reduction of power output.The power output not only depends upon the ambient temperature, but, also on the temperature of the cell inside the PV panel.

As the temperature of the PV panel increases, there is an exponential increase in the output current,but linear reduction of voltage.The data sheet of the PV panel, mentions the temperature coefficient percentage.It basically explains the \%age change in PV panel efficiency depending upon the change in temperature.For places where frequent change in temperature takes place, a great care is to be taken to minimise the high temperature effects.This can be done by installing the PV panels in such a manner so that there is proper air flow aroud them. 


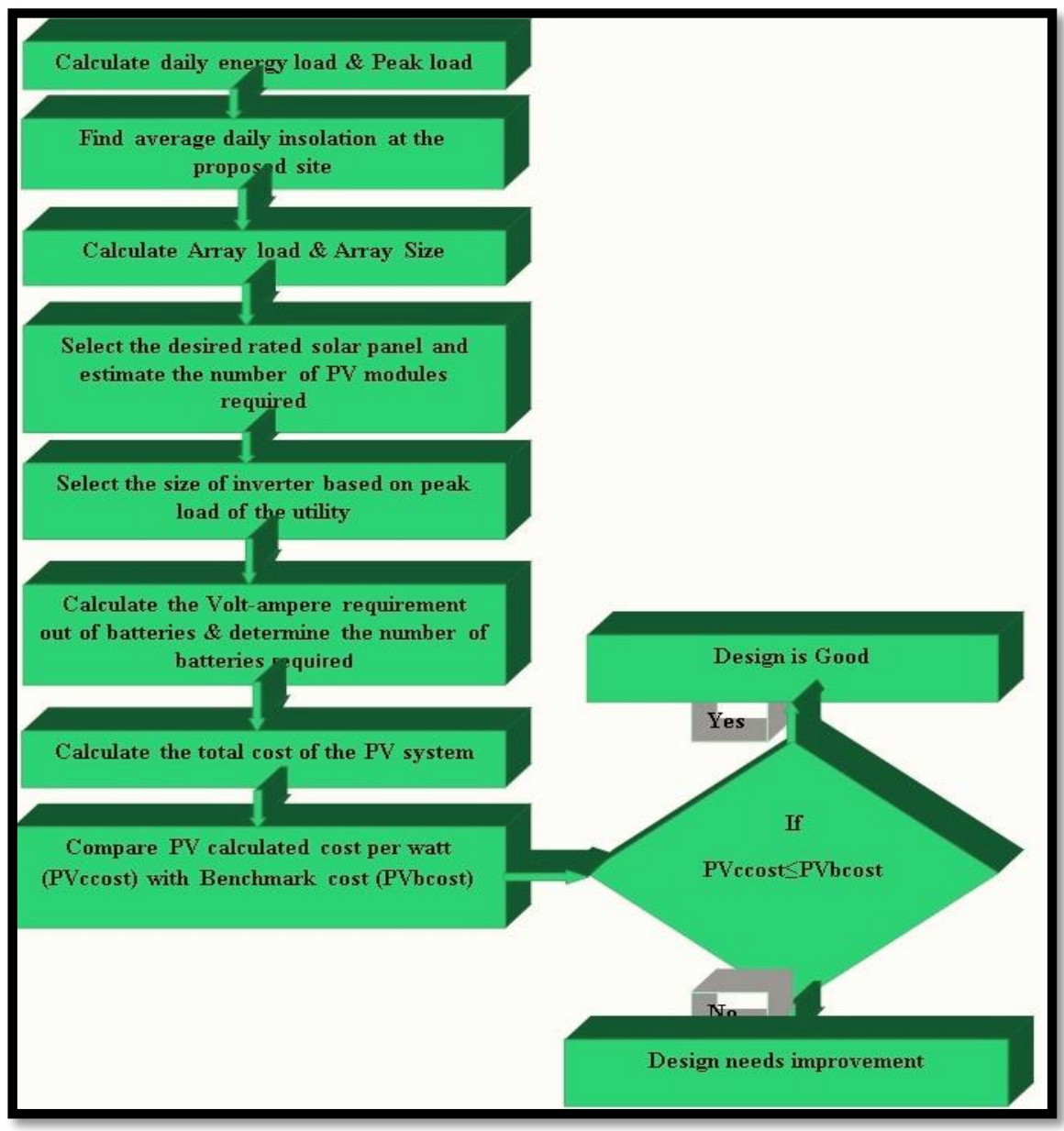

Figure.4 Proposed Flow chart for designing the PV system

\subsection{Inverter Efficiency}

An inverter is required to supply the AC load. The efficiency of the inverter has improved very much during the past decades. Several inverter configurations are available,touching $98 \%$ of efficiency. The size of the inverter is chosen from the solar array size and a peak load of the utility. An additional margin is also kept for future expansion. A typical value of 1.2 for DC to AC is considered reasonable.

The best/optimal selection of these components and various other factors taken together, will result in the heavy cost spend to install the PV system. There are certain procedural steps necessary to be taken, for the efficient design of the PV system. A systematic procedure is proposed as shown in the form a flow chart (Figure.4) to help the designer/utilities, etc. to correctly size the PV system, and to ascertain, whether the PV design accomplished is good/bad or needs some improvement. The decision taken, is based on the method of benchmarking, whereby the government organization such as Ministry of New \& Renewable Energy (MNRE) provides the benchmark costs of the PV system per kW [23-24]. It helps the designer, to control costs and gain profits with better efficiency. It also helps in making efficient decisions like component selection, component substitution, or any other suitable alternatives.

\section{Result and Discussion}

\subsection{Power Output and Cost of Energy}

The detailed information presented in the above section is utilized, to analyse the differences in the selection of solar photovoltaic technologies, and other design procedures for getting the optimal power output. Two districts (Rajouri \& Poonch) of J \& K UT are considered in our research.A detailed study is carried out, regarding the choice of different PV technologies, to find the estimated power output with cost analysis. Figure.5 shows the latitude-longitude map of the regions [25]. Three types of solar modules are considered in our study.Also, these three modules are kept in fixed,singleaxis tracking and double-axis tracking positions, to estimate the differneces, in the amount of solar radiations received and power outputs generated. 


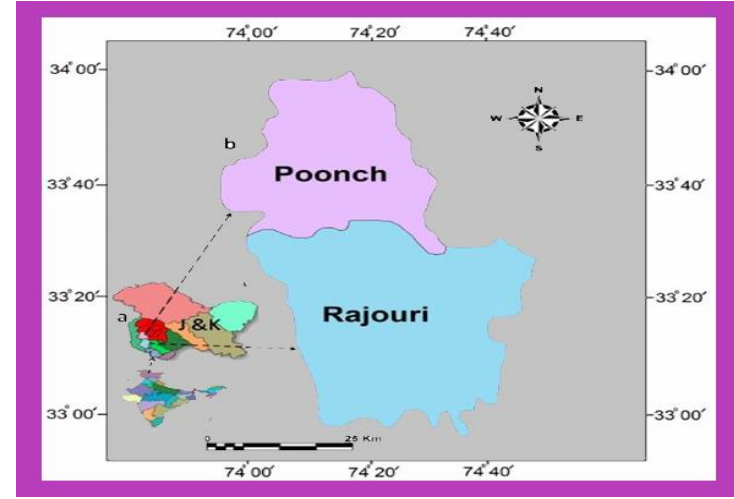

Figure.5 Latitude \& Longitude diagram of Rajouri and Poonch

Table.Il Rating of chosen parameters kept

\begin{tabular}{c|c|c}
\hline S.No & Particular & Remarks \\
\hline 1. & Solar radiation source & NREL(TMY) \\
\hline 2. & System Losses & $14 \%$ \\
\hline 3. & Efficiency of Inverter & $96 \%$ \\
\hline 4. & Annual degradation factor & $0.5 \%$ \\
\hline 5. & Life of the plant & 25 years \\
\hline 6. & Tracking mechanisms & All \\
\hline 7. & $\begin{array}{c}\text { Average Cost of per unit of } \\
\text { electricity }\end{array}$ & Rs. 5/kWh \\
\hline & & \\
\hline
\end{tabular}

The detailed analysis is carried out using the above design procedures with the aid of various software such as PV watts calculator, System Advisor Model (SAM) of National renewable energy laboratory (NREL) [26]. The values of various input parameters which have been kept in the design procedure are shown in Table. II.

Five output parameters have been evaluated, using different types of solar photovoltaic technologies both for Rajouri and Poonch. For Rajouri (latitude: 33.5 \& longitude:74.35), the size of the Photovoltaic system of 1 Megawatt (MW) was considered. The power output and cost of energy were evaluated, using different design procedures as shown in
Table.III. Two graphs are also plotted, to find out the highest power output and the cost of energy involved.The highest power output and highest cost of energy is supplied, using monocrystalline solar panels with a double-axis tracker as shown in Figure.6 \& Figure.7.simultaneously. The same analogy has been kept, for the Poonch district (latitude: 33.75 and longitude: 74.05) of J \& K UT. The results obtained, are depicted in Table.III, Figure. 8 \& Figure. 9 accordingly.

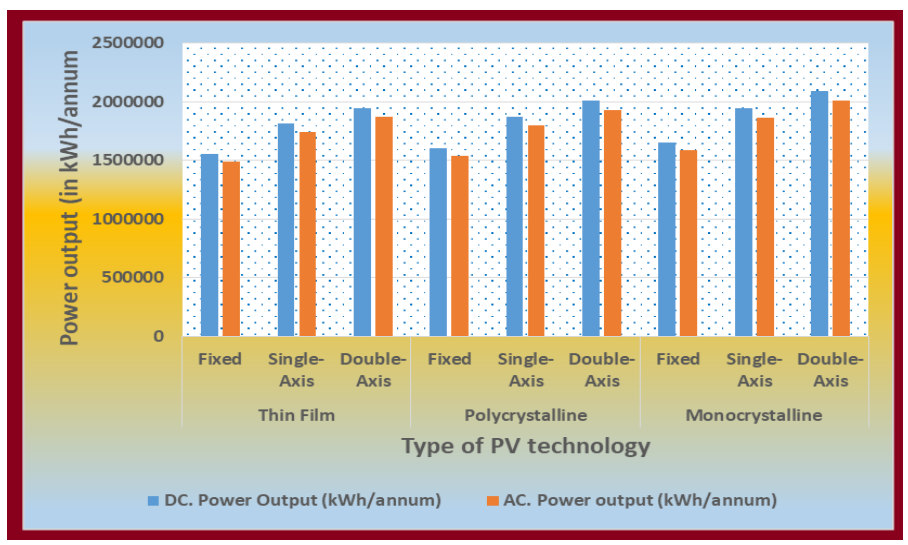

Figure.6 Power output vs. Type of photovoltaic technology for district Rajouri

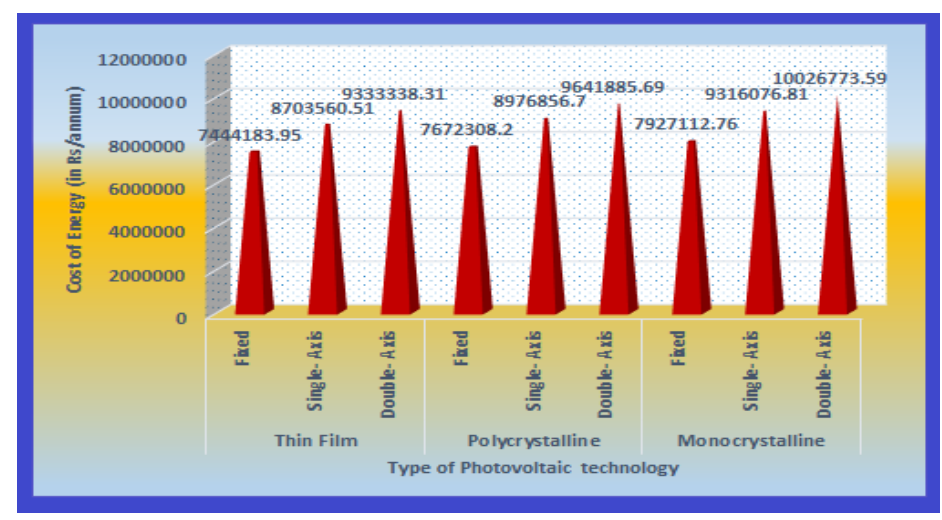

Figure.7 Cost of Energy vs. Type of Photovoltaic technology for district Rajouri

Table.III Analysis for district Rajouri (J\&K)

\begin{tabular}{|c|c|c|c|c|c|c|}
\hline \multicolumn{3}{|l|}{ Case I: Rajouri } & \multicolumn{2}{|l|}{ Latitude: 33.35} & \multicolumn{2}{|c|}{ Longitude: 74.35} \\
\hline Type of Panel & $\begin{array}{l}\text { Type of } \\
\text { Tracking }\end{array}$ & $\begin{array}{l}\text { Solar } \\
\text { radiations } \\
\left(\mathrm{kW} / \mathrm{m}^{2} / \text { day }\right)\end{array}$ & $\begin{array}{l}\text { DC. Power Output } \\
\text { (kWh/annum) }\end{array}$ & $\begin{array}{l}\text { AC. Power } \\
\text { output } \\
\text { (kWh/annum) }\end{array}$ & $\begin{array}{l}\text { Cost of } \\
\text { Energy } \\
\text { (Rs/annum) }\end{array}$ & $\begin{array}{l}\text { Capacity } \\
\text { Factor }\end{array}$ \\
\hline \multirow[t]{3}{*}{ Thin Film } & Fixed & 5.55 & 1553391.172 & 1488836.789 & 7444183.95 & 17 \\
\hline & Single- Axis & 6.45 & 1814010.453 & 1740712.102 & 8703560.51 & 19.9 \\
\hline & Double- Axis & 6.99 & 1944632.477 & 1866667.664 & 9333338.31 & 21.3 \\
\hline \multirow[t]{3}{*}{ Polycrystalline } & Fixed & 5.55 & 1600935.242 & 1534461.641 & 7672308.2 & 17.5 \\
\hline & Single- Axis & 6.45 & 1871068.273 & 1795371.336 & 8976856.7 & 20.5 \\
\hline & Double- Axis & 6.99 & 2009111.313 & 1928377.133 & 9641885.69 & 22.0 \\
\hline \multirow[t]{3}{*}{ Monocrystalline } & Fixed & 5.55 & 1654169.961 & 1585422.555 & 7927112.76 & 18.1 \\
\hline & Single- Axis & 6.45 & 1941980.672 & 1863215.359 & 9316076.81 & 21.3 \\
\hline & Double- Axis & 6.99 & 2089709.828 & 2005354.719 & 10026773.59 & 22.9 \\
\hline
\end{tabular}


Table.IV Analysis for district Poonch

\begin{tabular}{|c|c|c|c|c|c|c|}
\hline \multicolumn{2}{|l|}{ Case II: Poonch } & \multicolumn{2}{|c|}{ Latitude: 33.75} & \multicolumn{3}{|c|}{ Longitude:74.05 } \\
\hline Type of Panel & $\begin{array}{l}\text { Type of } \\
\text { Tracking }\end{array}$ & $\begin{array}{l}\text { Solar } \\
\text { radiations } \\
\left(\mathrm{kW} / \mathrm{m}^{2} / \text { day }\right)\end{array}$ & $\begin{array}{l}\text { DC. Power Output } \\
\text { (kWh/annum) }\end{array}$ & $\begin{array}{l}\text { AC.Power } \\
\text { output } \\
\text { (kWh/annum) }\end{array}$ & $\begin{array}{l}\text { Cost of Energy } \\
\text { (Rs/annum) }\end{array}$ & $\begin{array}{l}\text { Capacity } \\
\text { Factor }\end{array}$ \\
\hline \multirow[t]{3}{*}{ Thin Film } & Fixed & 5.56 & 1576713.461 & 1511371.906 & 7556859.52 & 17.3 \\
\hline & Single- Axis & 6.49 & 1839831.5 & 1765630.664 & 8828153.31 & 20.2 \\
\hline & Double- Axis & 7.00 & 1972460.219 & 1893489.945 & 9467449.72 & 21.6 \\
\hline \multirow[t]{3}{*}{ Polycrystalline } & Fixed & 5.56 & 1618956.383 & 1551891.461 & 7759457.32 & 17.7 \\
\hline & Single- Axis & 6.49 & 1890182.195 & 1813845.406 & 9069227.03 & 20.7 \\
\hline & Double- Axis & 7.00 & 2029757.102 & 1948303.688 & 9741518.45 & 22.2 \\
\hline \multirow[t]{3}{*}{ Monocrystalline } & Fixed & 5.56 & 1665588.039 & 1596513.281 & 7982566.41 & 18.2 \\
\hline & Single- Axis & 6.49 & 1952707.984 & 1873651.344 & 9368256.72 & 21.4 \\
\hline & Double- Axis & 7.00 & 2101377.867 & 2016743.43 & 10083717.18 & 23 \\
\hline
\end{tabular}

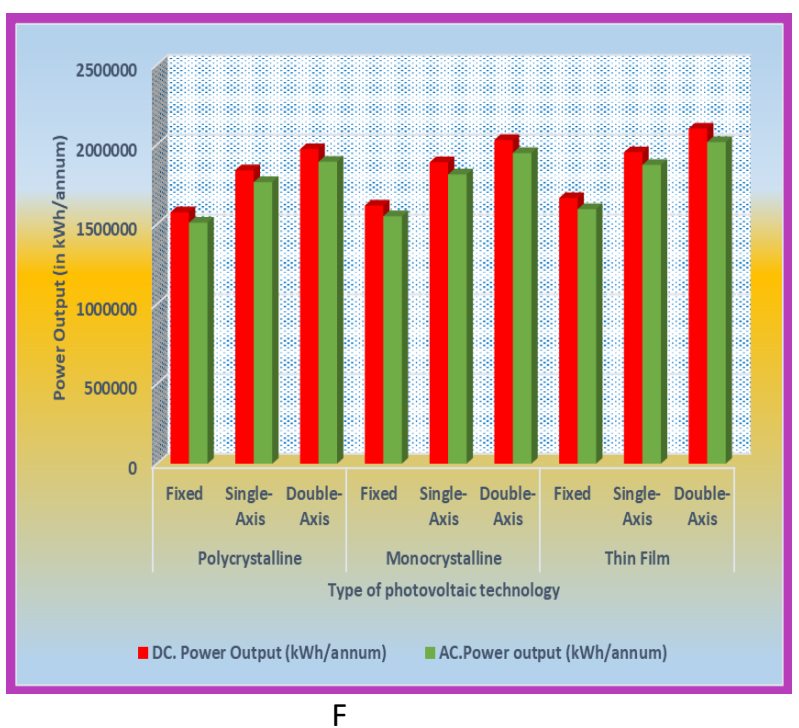

Figure.8 Power output vs. Type of photovoltaic technology

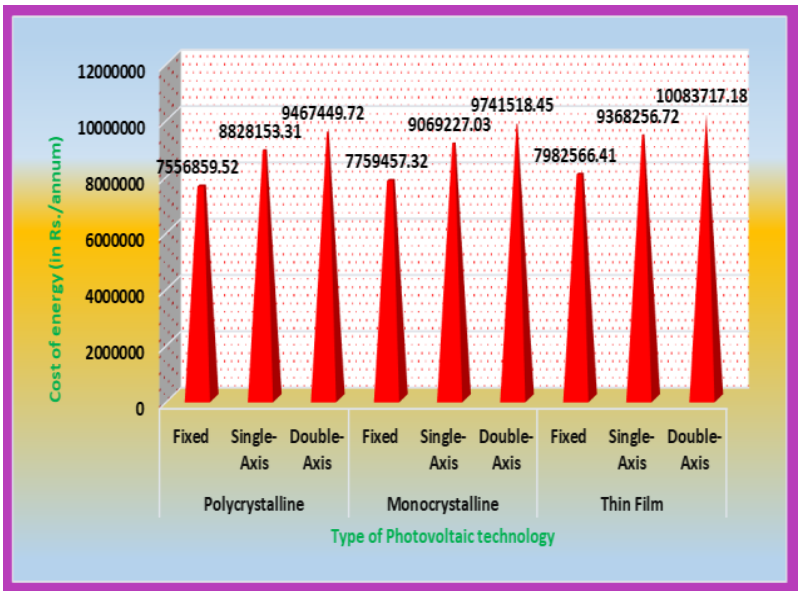

Figure. 9 Cost of Energy vs. Type of Photovoltaic technology

\subsection{Financial Analysis and outcome}

The J\&K UT can install the PV systems by their expenditure or offer the enterprises to follow the Build Own Operate (Transfer) BOO(T) Model to install the PV system, if they are hesitant, owing to the initial investment required in building the PV system. This model allows the utilities to consume the electricity generated through PV plants and an option of transfer in the future as well to the utilities after a certain gap of agreement.

To help the utilities in taking a decision, a return on investment is also carried out to find out the levelised cost of electricity (LCOE) for Rajouri \& Poonch based on the results that we have obtained in the above discussion. The annual yield for both locations is found using the annual power output and size of the solar plant for different PV technologies. Using it and by selecting several other parameters (Table.V.) different return on investment parameters are computed for both the locations as shown in Table.VI.

Table.V Parameters chosen for return on investment

\begin{tabular}{|c|c|c|}
\hline S.No & Parameter & Value \\
\hline 1 & Life of Plant & 25 years \\
\hline 2 & Nominal Power & $1000 \mathrm{kWp}$ \\
\hline 3 & Degradation factor & $0.5 \% /$ year \\
\hline 4 & Feed in tariff & Rs. 5/kWh for 20 years \\
\hline 5 & $\begin{array}{l}\text { Current Price of } \\
\text { Electricity \& its inflation }\end{array}$ & $\begin{array}{l}\text { Rs.5/kWh with } \\
\text { inflation of } 2 \% \text { /year }\end{array}$ \\
\hline 6 & Maintenance cost & $0.5 \% /$ year \\
\hline 7 & Inflation rate & $2 \%$ \\
\hline
\end{tabular}

For both districts, a total of nine cases are considered which are evaluated for three parameters: Amortisation time, Levelised cost of electricity, and internal rate of return. It was revealed that the levelised cost of electricity was found to vary between Rs.1.811 to Rs. 2.454 per kilowatt-hour (kWh) indicating, that it's a very good investment. The graphical representation for both locations is shown in Figure.10 and Figure.11. 
Table.VI. Obtained values of various financial indices for different types of PV technologies.

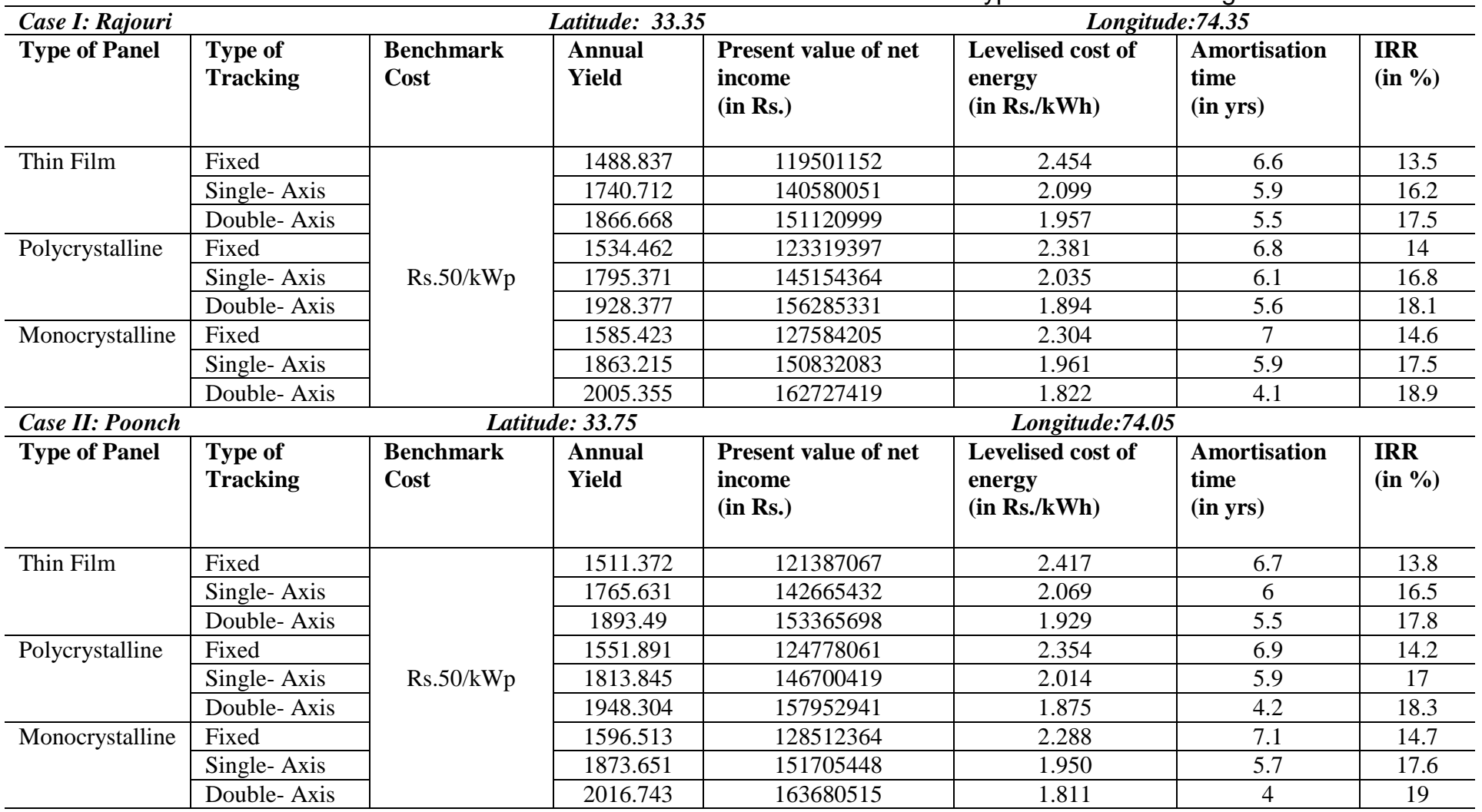

\section{CASE: DISTRICT RAJOURI}

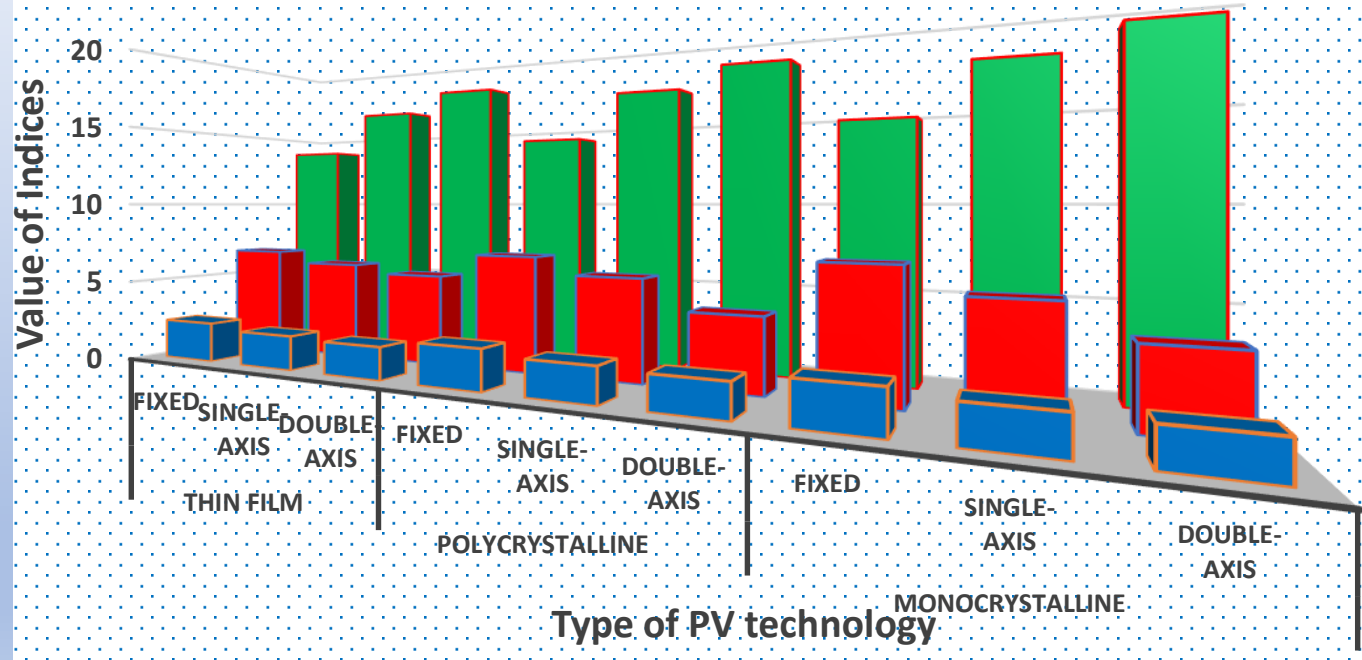

n Levelised cost of energy (in Rs./kWh) घAmortisation time (in yrs) $\quad$ IRR (in \%)

Figure.10 Graphical representation of various financial indices against different PV technologies 


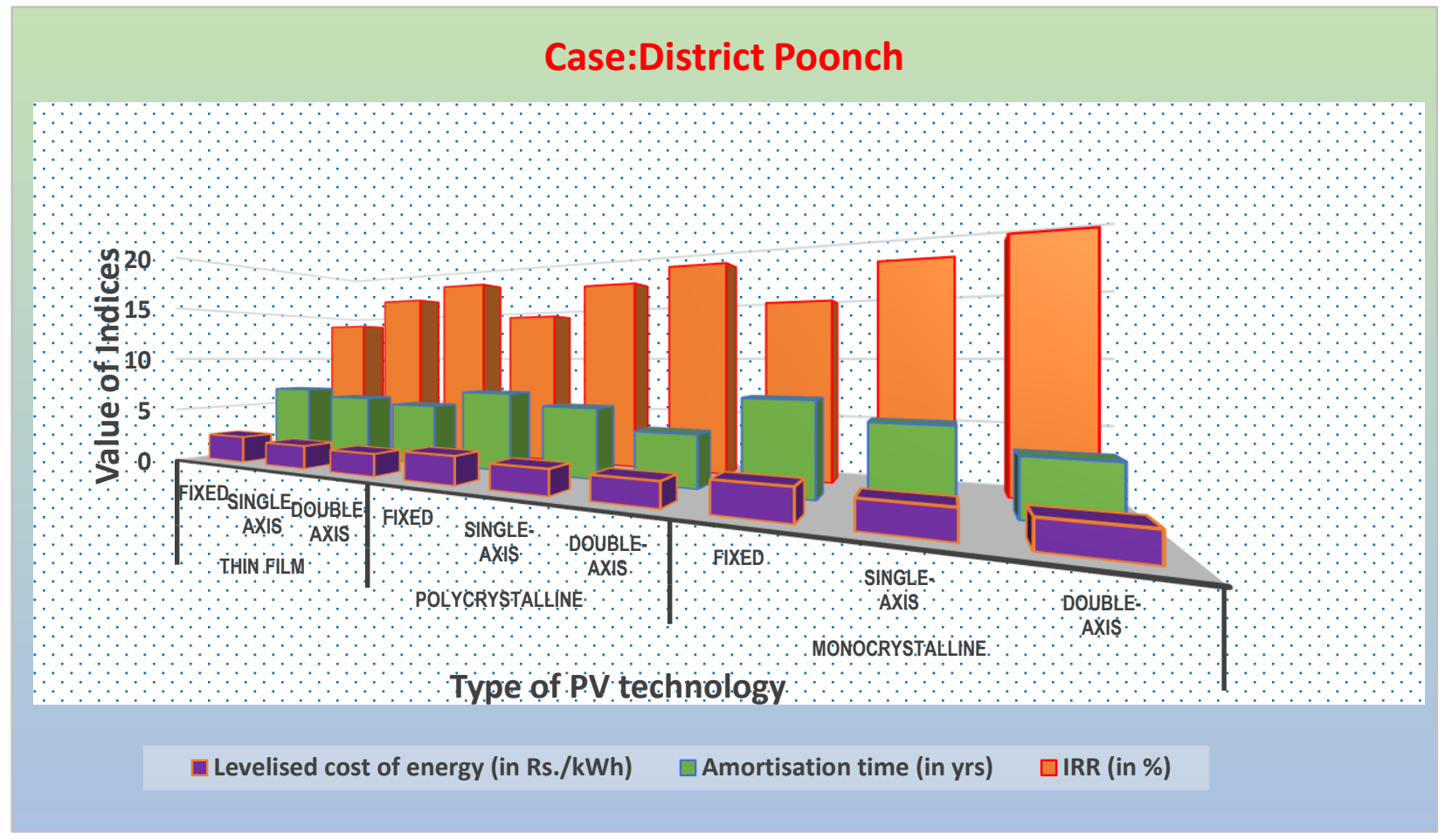

Figure.11 Graphical representation of various financial indices against different PV technologies

\section{Conclusion}

In this paper, different types of PV technologies were analysed for power output and the cost of energy. It was revealed that the efficiency of the PV system increases, using a tracking mechanism instead of fixed panels. Also, it was found that the power output of Monocrystalline is highest among all other types of solar panels. However solar panels with a tracking mechanism and monocrystalline are found very costly.

This study will help the power analysts/utilities in deciding to choose, which type of PV technology would be beneficial from them, depending upon the load requirement and various costs involved. It was also found, that using PV system in two places (Rajouri \& Poonch) will be very beneficial, since both of these places are receiving good amount of solar radiations, due to their geographical location. This will solve the long pending demand of the people of these places, to receive better power, which is pollution-free thereby saving the environment too.The estimated levelised cost of electricity for both regions is found to vary between Rs.1.811 and Rs. 2.454 per kilowatt-hour (kWh).This indicates it's a very good investment. This much cost, is highly competitive as compared to what we are paying currently.

\section{References}

[1]. Makbul. A.M Ramli, Ayong hiendro, Khalid Sedraoui, Ssennoga Twaha.(2015) "Optimal sizing of grid-connected photovoltaic energy system in Saudi Arabia." Renewable Energy,Volume75,March,2015,pp.489-495 https://doi.org/10.1016/j.renene.2014.10.028

[2]. Mekhilef S., Saidur R,Safari A. (2011) "A review on solar energy use in industries." Renewable Sustainable Energy Reviews. 2011; 15:1777-90.

[3]. Cheng J., Choobineh FF. (2017) "A comparative study of the storage assisted wind power conversion systems.” In: 2017 6th International Conference on Clean Electrical Power (ICCEP). IEEE, pp 608-613.

[4]. Arhun S., Hnatov A., Dziubenko O., Ponikarovska S. (2019) "A Device for Converting Kinetic Energy of Press Into Electric Power as a Means of Energy Saving." Journal of the Korean Society for Precision Engineering 36:105-110 https://doi.org/10.7736/KSPE.2019.36.1.105

[5]. Hnatov A., Arhun S., Dziubenko O., Ponikarovska S. (2018) "Choice of Electric Engines Connection Circuits in Electric Machine Unit of Electric Power Generation Device." Majlesi Journal of Electrical Engineering 12:87-95

[6]. Milano J., Ong HC., Masjuki HH., Chong WT., Lam MK., Loh PK., Vellayan V. (2016) "Microalgae biofuels as an alternative to fossil fuel for power generation." Renewable and Sustainable Energy Reviews 58:180-197

[7]. Marta Victoria., Gorm B. Andresen.(2019) "Using validated reanalysis data to investigate the impact of the PV system configurations at high penetration levels in European countries." Progress in Photovoltaics: Research and Applications; DOI: 10.1002/pip.3126 
[8]. https://www.renewableenergyworld.com/2020/04/28/bnefsays-solar-and-wind-are-now-cheapest-sources-of-newenergy-generation-for-majority-of-planet/\#gref

[9]. Muneer T., Asif M., Munawwar S. (2005). "Sustainable production of solar electricity with particular reference to the Indian economy". Renewable and Sustainable Energy Reviews. 9 (5): 444. doi:10.1016/j.rser.2004.03.004.

[10]. "Solar". Ministry of New and Renewable Energy, Govt. of India. Archived from the original on 25 February 2014. Retrieved 21 February 2014.

[11]. "Physical Progress (Achievements)". Ministry of New \& Renewable Energy.

[12]. "Annual Report 2015-2016". Ministry of New \& Renewable Energy.

[13]. "Solar water pumps can help India surpass $100 \mathrm{GW}$ target: Report". Retrieved 2 August 2017.

[14]. https://www.greaterkashmir.com/news/more/news/rajouripoonch-plunge-into-darkness/?amp

[15]. Mughal S.N. (2015) "J and K- A Power Potential Source or Power Deficit State" International Journal of Research and Scientific Information, Vol.II, Issue VII July 2015,pp.1417(ISSN:2321-2705)

[16]. https://energy.economictimes.indiatimes.com/news/power/jk-faces-power-shortage-of-408-mw/72368887

[17]. Mughal S.N., Sood Y.R., Jarial R.K. (2018) "A review on Solar Photovoltaic technology and future trends", International Journal of Scientific Research in Computer Science Engineering and Information technology(IJSRCSEIT-2018), Vol 4, Issue1, ISSN: 2456-3307

[18]. Ministry of New \& Renewable Energy, Memorandum "Operational guidelines for implementation of Phase-II of Grid connected Rooftop solar programme for achieving cumulative capacity of 40,000 MW from Rooftop Solar(RTS) Projects by the year 2022.dated-20,Aug,2019.

[19]. Mughal S.N., Sood Y.R., Jarial R.K. (2019) Design and Techno-Financial Analysis of Solar Photovoltaic Plant for School of Engineering and Technology at BGSB University, Rajouri (J\&K).Applications of Computing, Automation, and Wireless Systems in Electrical Engineering. Lecture Notes in Electrical Engineering, Vol 553. Springer, Singapore. pp. 231243

[20]. Patḷins A., Arhun S., Hnatov A., Dziubenko O., Ponikarovska S. (2018) "Determination of the Best Load Parameters for Productive Operation of PV Panels of Series FS-100M and FS110P for Sustainable Energy Efficient Road Pavement.” In: 2018 IEEE 59th International Scientific Conference on Power and Electrical Engineering of Riga Technical University (RTUCON 2018): Conference Proceedings. Riga, Latvia, pp 16

[21]. Jiang F., Wong A. (2005) "Study on the performance of different types of PV modules in Singapore." In: 2005 International Power Engineering Conference. IEEE, pp 1-109

[22]. Hasan N. Muslim. (2018) "Solar Tilt Angle Optimization of PV Systems for Different Case Studies" EAI Endorsed Transactions on Energy Web. Volume 6, Issue 23, e7, doi: 10.4108/eai.13-7-2018.157038

[23]. RICS Practice Standards, UK (2011). "Cost analysis and benchmarking" (PDF). RICS QS \& Construction Standards. 1.

[24]. "Benchmark costs for Grid Connected Rooftop Solar Power Plants for the Year 2019-20."Ministry of New \& Renewable Energy. https://mnre.gov.in/solar/standard-specs-cost

[25]. Dar Gh. Hassan.,Malik Akhtar H.,Khuroo Anzar A.(2014) “A Contribution to the Flora of Rajouri and Poonch Districts in the
Pir Panjal Himalaya (Jammu \& Kashmir), India” Check List 10(2): 317-328, 2014, Journal of species lists and distribution. [26]. https://pvwatts.nrel.gov/

[27]. https://el-engineering.com 